ISSN 0258-7122

Bangladesh J. Agril. Res. 37(3): 441-447, September 2012

\title{
STUDY ON THE PHYSICO-CHEMICAL CHARACTERISTICS OF LONGAN (Euphoria longana) GERMPLASM
}

\author{
M. M. KHATUN ${ }^{1}$, M. R. KARIM ${ }^{2}$, M. M. MOLLA ${ }^{3}$ \\ M. M. KHATUN ${ }^{4}$ AND M.J. RAHMAN ${ }^{5}$
}

\begin{abstract}
A study on the physico-chemical characteristics of 15 promising longan germplasm was carried out at the fruit Research Farm of Horticulture Research Centre (HRC) as well as laboratory of Post harvest Technology Section of HRC and the Central Laboratory of Bangladesh Agricultural Research Institute, Joydebpur, Gazipur. The experiment was conducted during the fruiting season of 2010. Fifteen promising lines of longan germplasm including BARI Anshphal-1, BARI Anshphal-2, EL-Joy 003 to EL-Joy 015 of 12 years old were included in this experiment. A wide range of variations were observed among the germplasm in respect of different characteristics under the present study. Per cent edible portion was the highest in EL-Joy 010 (76.57 \%), EL-Joy 006 (74.55\%), EL-Joy 003 (74.20 \%) and the lowest in EL-Joy 012 (65.10 \%). Total reducing and non-reducing sugar was the maximum in EL-Joy 009 (6.94 \%) and BARI Anshphal-2 (16.50 \%), respectively. BARI Anshphal-1 contained the highest amount of ascorbic acid (13.00 mg/100 g) and EL-Joy 009 possessed the maximum total soluble solids $(22.30 \%)$. The study revealed that BARI Anshphal-1, BARI Anshphal-2, EL-Joy 003, EL-Joy 006, EL-Joy 009, EL-Joy 010 were the best in respect of physical and chemical characteristics of fruits.
\end{abstract}

Keywords: Longan, physico-chemical characteristics, Vitamin-C.

\section{Introduction}

The longan (Euphoria longana) is a highly esteemed arilloid fruit species in Asia and belongs to the family of Sapindaceae. The word 'longan' or 'long yan' or 'lungngan' comes from the Chinese and literally means 'dragon-eye' which is an apt description of the fruit after the skin has been removed. It grows satisfactorily in a wide range of tropical and subtropical countries but is exploited commercially only in Thailand, China, Taiwan and recently in Vietnam (Wong, 2000). Like the lychee, longan is adapted to a subtropical environment with warm, humid summer and cool, dry winter. Nevertheless, it doesn't tolerate temperatures below $32^{0} \mathrm{~F}\left(0^{0} \mathrm{C}\right)$, and temperatures of 26 to $28^{0} \mathrm{~F}$ (-2 to $-3^{0} \mathrm{C}$ ) can cause severe damage or death to young trees (Anon, 2007). In the tropics, longan can be grown from sea level to 1,800 feet $(549 \mathrm{~m})$ altitude. The longan is adaptable to different soils, but doesn't tolerate water logging or saline conditions (Anon., 2007). Growth is the best in fertile, deep soils with a pH of 5.5 to 6 . The

${ }^{1,2, .3 \& 4}$ Scientific Officer, ${ }^{5}$ Senior Scientific Officer, Horticulture Research Centre (HRC), Bangladesh Agricultural Research Institute (BARI), Gazipur-1701, Bangladesh. 
climatic condition of Bangladesh may be suitable for longan cultivation. The longan resembles the lychee (Litchi chinensis). Fruit can be eaten fresh, frozen, canned or dried. It contains 109.0 calorie, $1.0 \mathrm{~g}$ protein, $0.5 \mathrm{~g}$ fat, $25.2 \mathrm{~g}$ carbohydrate, $2.0 \mathrm{mg}$ calcium, $0.3 \mathrm{mg}$ iron, $6.0 \mathrm{mg}$ phosphorus, 28.0 I.U. vitamin A, $8.0 \mathrm{mg}$ vitamin C per $100 \mathrm{~g}$ of edible fruit (Wong and Saichol, 1991). Longan was introduced in Bangladesh in early sixties. As it is an introduced fruit, the information of fruiting behaviour of this fruit is scanty. Only one experiment on performance of longan at joydebpur condition was carried out (Saifullah, 1996). The detailed study on longan fruits has not been carried out in this country. So the present study was undertaken to select superior genotypes in respect of fruit quality.

\section{Materials and Method}

A study on the physico-chemical characteristics of 15 promising longan germplasm was carried out at the fruit Research Farm of Horticulture Research Centre (HRC) as well as laboratory of Post Harvest Technology Section of HRC, Central Laboratory of Bangladesh Agricultural Research Institute, Joydebpur, Gazipur. The experiment was conducted during the fruiting season of 2010. Fifteen promising lines of longan germplasm including BARI Anshphal-1, BARI Anshphal-2, EL-Joy 003 to EL-Joy 015 of 12 years old were included in this experiment. The seedling plants were planted in 1997 at $4 \mathrm{~m} \times 4 \mathrm{~m}$ spacing. Single plant of each germplasm was considered as one replication.

For this study, 30 mature fruits were collected randomly from each plant. After collection, the fruits were kept on the laboratory desk at ambient condition for recording physical and chemical characteristics. Twenty full ripe fruits per plant were used for physical characteristics and rest ten fruits were taken to the Bio-chemistry Laboratory for chemical analysis. Data on different parameters of fruits were recorded according to book of "Longan Production in Asia" edited by Wong Kai Choo (2000) with the help of digital balance, vision refractometer. Organoleptic tests were done by a pannel of three members. Data on different parameters were recorded and analyzed statistically.

\section{Results and Discussion}

\section{Quantitative characteristics of longan fruits}

The qualitative and quantitative characteristics of fruits of some longan genotypes are presented in Table 1 and 2. Wide range of variability was observed among the genotypes under study in respect of different physical and chemical characteristics of fruits. Fruit weight of different genotype varied from 3.65g to 8.80g. The highest fruit weight was recorded in the genotypes EL-Joy 013 (8.80g) and EL-Joy 015 (8.80g) followed by EL-Joy 010 (7.94g), EL-Joy 014 
(7.65g) and EL-Joy 012 (7.45g). The lowest fruit weight was obtained from the variety BARI Anshphal-1 (3.65g). The length and diameter of fruits varied from 1.67 to $2.38 \mathrm{~cm}$ and 1.86 to $2.63 \mathrm{~cm}$, respectively. The maximum fruit length was found in EL-JOY $012(2.38 \mathrm{~cm})$ and EL-Joy $013(2.38 \mathrm{~cm})$, whereas the minimum in BARI Anshphal-1 $(1.67 \mathrm{~cm})$. The maximum fruit diameter was obtained from EL-Joy $010(2.63 \mathrm{~cm})$, while the minimum from BARI Anshphal$1(1.86 \mathrm{~cm})$. Morton (1987) reported that fruits are 1.25-2.50 cm in diameter. The highest rind weight was recorded in EL-Joy 015 (1.40g) followed by EL-Joy 012 $(1.25 \mathrm{~g})$ and EL-Joy 013 (1.33 g) whereas, the lowest in EL-Joy 008 (0.44 g). The weight of aril was the highest in EL-Joy 010 (6.08g) closely followed by ELJoy 015 (6.00g) and EL-Joy 013 (5.87 g), while the lowest in BARI Anshphal-1 (2.62 g). The heaviest seed (1.60 g) was obtained from EL-Joy 013 (1.60 g), whereas the lightest from the variety BARI Anshphal-1 (0.45 g) (Fig. 1). Percent edible portion of fruits ranged from 65.10 to $76.57 \%$. The highest percentage of edible portion was recorded in the germplasm EL-Joy 010 (76.57 \%) followed by EL-Joy 006 (74.55 \%), EL-Joy 003 (74.02 \%), and EL-Joy 005 (72.68 \%) while the lowest in EL-Joy 012 (65.10 \%). Wong (2000) stated that the aril constitute from 60 to 75 percent of the total fruit weight.

Table 1. Quantitative characteristics of fruits of some longan genotypes

\begin{tabular}{lcc|c|c|c|c|c}
\hline \multicolumn{1}{c|}{ Treatment } & $\begin{array}{c}\text { Fruit wt. } \\
(\mathrm{g})\end{array}$ & $\begin{array}{c}\text { Fruit } \\
\text { length } \\
(\mathrm{cm})\end{array}$ & $\begin{array}{c}\text { Fruit } \\
\text { diameter } \\
(\mathrm{cm})\end{array}$ & $\begin{array}{c}\text { Aril wt } \\
(\mathrm{g})\end{array}$ & $\begin{array}{c}\text { Rind wt } \\
(\mathrm{g})\end{array}$ & $\begin{array}{c}\text { Seed wt } \\
(\mathrm{g})\end{array}$ & $\begin{array}{c}\text { Edible } \\
\text { portion } \\
(\%)\end{array}$ \\
\hline BARI Anshphal-1 & 3.65 & 1.67 & 1.86 & 2.62 & 0.58 & 0.45 & 71.78 \\
BARI Anshphal-2 & 5.25 & 2.03 & 2.11 & 3.51 & 0.72 & 1.02 & 66.86 \\
EL-Joy 003 & 5.85 & 2.20 & 2.31 & 4.33 & 0.65 & 0.87 & 74.02 \\
EL- Joy 004 & 6.60 & 2.32 & 2.49 & 4.35 & 1.02 & 1.23 & 65.91 \\
EL- Joy 005 & 5.49 & 2.02 & 2.19 & 3.99 & 0.61 & 0.89 & 72.68 \\
EL- Joy 006 & 6.17 & 2.18 & 2.28 & 4.60 & 0.55 & 1.02 & 74.55 \\
EL- Joy 007 & 6.45 & 2.08 & 2.22 & 4.47 & 0.93 & 1.05 & 69.30 \\
EL- Joy 008 & 4.77 & 2.06 & 2.03 & 3.26 & 0.44 & 1.07 & 68.34 \\
EL- Joy 009 & 5.57 & 2.04 & 2.18 & 3.92 & 0.50 & 1.15 & 70.38 \\
EL- Joy 010 & 7.94 & 2.30 & 2.63 & 6.08 & 0.63 & 1.23 & 76.57 \\
EL- Joy 011 & 6.34 & 2.12 & 2.38 & 4.44 & 0.69 & 1.21 & 70.03 \\
EL- Joy 012 & 7.45 & 2.38 & 2.55 & 4.85 & 1.25 & 1.35 & 65.10 \\
EL- Joy 013 & 8.80 & 2.38 & 2.48 & 5.87 & 1.33 & 1.60 & 66.70 \\
EL- Joy 014 & 7.65 & 2.36 & 2.46 & 5.20 & 0.95 & 1.50 & 67.97 \\
EL- Joy 015 & 8.80 & 2.31 & 2.43 & 6.00 & 1.40 & 1.40 & 68.18 \\
\hline Mean & 6.45 & 2.16 & 2.31 & 4.50 & 0.82 & 1.14 & 69.89 \\
SD & 1.46 & 0.19 & 0.21 & 1.00 & 0.31 & 0.28 & 3.41 \\
CV (\%) & 22.68 & 8.87 & 9.15 & 22.19 & 38.21 & 24.98 & 4.87 \\
\hline
\end{tabular}




\section{Qualitative characteristics of longan fruits}

Fruit shape of the germplasm was observed as roundish flat, round, irregularly round, heart shape. Among the germplasm, fruits of BARI Anshphal-1 were roundish flat, EL- Joy 004 irregularly round, EL- Joy 010 heart shape and rest of the fruit of the germplasm were round. Rind colour at ripen stage were brown, blackish brown, deep brown, reddish brown, and whitish brown. Most of the fruit colour was brown. Rind texture of the genotypes varied from smooth to slightly rough/warty. Seed colour of the genotypes were glossy black to glossy reddish black and seed shape varied from roundish flat to round. The seed shape of the variety BARI Anshphal-1 was roundish flat, whereas rest of the genotypes was roundish in shape. Only one seed was present in each fruit in all the germplasm. This findings supported with the findings of Wong (2000).Texture of the aril of all the genotypes was less juicy to very crispy, while aril colour of all the genotypes was translucent white and possessed sweet to bland flavour. The fruits of EL- Joy 010 germplasm were excellent in taste but the others were good to poor. Fruit attractiveness of all the genotypes was good to poor.

\section{Chemical characteristics of fruits in longan germplasm}

Chemical characteristics of different longan germplasm were presented in the Table 3. Total soluble solids (TSS) in the fruit ranged from 16.00 to $22.3 \%$. TSS was maximum in the genotype EL- Joy 009 (22.3\%) closely followed by EL- Joy 012 (21.7\%), EL- Joy 007 (21.5\%), EL- Joy 003 (21.20\%) and EL- Joy 008; ELJoy 014 (20.0\%) whereas, minimum in EL- Joy 013 (16.0\%). Wong (2000) reported that the aril has TSS values ranged from 15 to $25 \%$.

The highest moisture (80.0\%) was recorded in the variety BARI Anshphal-1, EL-Joy 004, EL-Joy 011, and EL- Joy 013, while the lowest percentage was recorded in BARI Anshphal 2 (74\%). The highest dry matter was recorded in BARI Anshphal-2 (26\%), whereas the lowest (20\%) in the genotypes BARI Anshphal 1, EL- Joy 004, EL- Joy 011, and EL- Joy 013. This result was similar to the findings of Wong and Saichol (1991).

The maximum total sugar (19.91\%) was recorded in the genotypes EL- Joy 009 followed by BARI Anshphal-2 (19.39\%), BARI Anshphal-1 (18.14\%) and EL- Joy 005 (17.86\%), while the minimum was recorded in EL- Joy 006 (9.18\%). The maximum reducing sugar was obtained from EL- Joy 009 (6.94\%), which was followed by the germplasm EL- Joy 012 (6.58\%), EL- Joy 011 (5.88\%) and EL- Joy 014 (5.21\%), whereas the minimum from EL- Joy 013 (2.59). The highest non-reducing sugar was recorded in the variety BARI Anshphal-1 (14.60\%), while the lowest in EL- Joy 007 (6.01\%). 
Table 2. Qualitative characteristics of fruits of some longan germplasm.

\begin{tabular}{|c|c|c|c|c|c|c|c|c|}
\hline Treatment & Fruit shape & Fruit colour & Rind texture & Seed colour & Seed shape & Aril texture & Flavor & $\begin{array}{l}\text { Eating } \\
\text { quality }\end{array}$ \\
\hline BARI Anshphal-1 & Roundish flat & Brown & Smooth & Glossy black & $\begin{array}{l}\text { Roundish } \\
\text { flat }\end{array}$ & Less juicy & Sweet & Good \\
\hline BARI Anshphal-2 & Round & $\begin{array}{l}\text { Blackish } \\
\text { Brown }\end{array}$ & $\begin{array}{l}\text { Slightly } \\
\text { rough }\end{array}$ & Glossy reddish black & Round & Very juicy & Sweet & Good \\
\hline EL-Joy 003 & Round & Brown & Smooth & Glossy reddish black & Round & Juicy & Sweet & Good \\
\hline EL- Joy 004 & $\begin{array}{l}\text { Irregular } \\
\text { round }\end{array}$ & Deep brown & Smooth & $\begin{array}{l}\text { Glossy light reddish } \\
\text { black }\end{array}$ & Round & $\begin{array}{l}\text { Very } \\
\text { crispy }\end{array}$ & Bland & Poor \\
\hline EL- Joy 005 & Round & $\begin{array}{l}\text { Whitish } \\
\text { brown }\end{array}$ & Smooth & Glossy reddish black & Round & Juicy & Sweat & Good \\
\hline EL- Joy 006 & Round & Brown & Smooth & Glossy reddish black & Round & Juicy & Sweet & Good \\
\hline EL- Joy 007 & Round & $\begin{array}{l}\text { Reddish } \\
\text { brown }\end{array}$ & Smooth & Glossy reddish black & Round & Juicy & Sweet & Intermediate \\
\hline EL- Joy 008 & Round & Brown & $\begin{array}{l}\text { Slightly } \\
\text { rough }\end{array}$ & Glossy black & Round & Juicy & Sweet & Good \\
\hline EL- Joy 009 & Round & Brown & Smooth & Glossy black & Round & Juicy & Sweet & Good \\
\hline EL- Joy 010 & Heart shaped & Brown & $\begin{array}{l}\text { Slightly } \\
\text { rough }\end{array}$ & $\begin{array}{l}\text { Glossy light reddish } \\
\text { black }\end{array}$ & Round & Crispy & Sweet & Excellent \\
\hline EL- Joy 011 & Round & Brown & Smooth & Glossy reddish black & Round & Juicy & Sweet & Good \\
\hline EL- Joy 012 & Round & Brown & $\begin{array}{l}\text { Slightly } \\
\text { rough }\end{array}$ & Glossy reddish black & Round & Juicy & $\begin{array}{c}\text { Slight } \\
\text { pungent }\end{array}$ & Good \\
\hline EL- Joy 013 & Round & Brown & Smooth & Glossy reddish black & Round & Juicy & $\begin{array}{l}\text { Slight } \\
\text { pungent }\end{array}$ & Good \\
\hline EL- Joy 014 & Round & Brown & Smooth & Glossy reddish black & Round & Juicy & $\begin{array}{c}\text { Slight } \\
\text { pungent }\end{array}$ & Good \\
\hline EL- Joy 015 & Round & Brown & Smooth & Glossy black & Round & Juicy & $\begin{array}{c}\text { Slight } \\
\text { pungent }\end{array}$ & Good \\
\hline
\end{tabular}

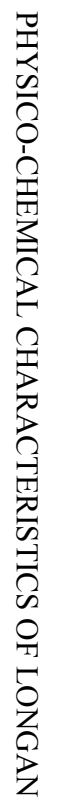


Table 3. Chemical characteristics of fruits of 15 longan genotypes.

\begin{tabular}{|c|c|c|c|c|c|c|c|c|}
\hline Treatments & $\begin{array}{l}\text { Percent } \\
\text { moisture }\end{array}$ & $\begin{array}{l}\text { Percent dry } \\
\text { matter }\end{array}$ & TSS (\%) & $\begin{array}{c}\text { Percent } \\
\text { reducing sugar }\end{array}$ & $\begin{array}{c}\text { Percent non- } \\
\text { reducing sugar }\end{array}$ & $\begin{array}{c}\text { Percent total } \\
\text { sugar }\end{array}$ & $\begin{array}{l}\text { Ascorbic acid } \\
(\mathrm{mg} / 100 \mathrm{~g})\end{array}$ & $\begin{array}{l}\beta \text {-carotene } \\
(\mathrm{mg} / 100 \mathrm{~g})\end{array}$ \\
\hline BARI Anshphal-1 & 80.0 & 20.0 & 19.1 & 3.52 & 14.60 & 18.14 & 13.77 & 0.40 \\
\hline BARI Anshphal-2 & 74.0 & 26.0 & 19.6 & 2.86 & 16.50 & 19.39 & 10.71 & 0.25 \\
\hline EL-Joy 003 & 78.0 & 22.0 & 21.2 & 4.63 & 7.66 & 12.29 & 7.80 & 0.35 \\
\hline EL- Joy 004 & 80.0 & 20.0 & 16.4 & 4.46 & 7.26 & 11.72 & 3.30 & 0.21 \\
\hline EL- Joy 005 & 78.0 & 22.0 & 19.5 & 3.01 & 14.85 & 17.86 & 5.90 & 1.29 \\
\hline EL- Joy 006 & 77.0 & 23.0 & 19.5 & 2.91 & 6.27 & 9.18 & 7.60 & 1.32 \\
\hline EL- Joy 007 & 79.0 & 21.0 & 21.5 & 3.68 & 6.01 & 9.69 & 4.40 & 1.31 \\
\hline EL- Joy 008 & 78.0 & 22.0 & 20.0 & 3.55 & 10.34 & 13.89 & 2.90 & 1.33 \\
\hline EL- Joy 009 & 76.0 & 24.0 & 22.3 & 6.94 & 12.97 & 19.91 & 5.00 & 1.02 \\
\hline EL- Joy 010 & 76.0 & 24.0 & 19.3 & 3.79 & 12.51 & 16.30 & 5.60 & 1.60 \\
\hline EL- Joy 011 & 80.0 & 20.0 & 19.3 & 5.88 & 11.04 & 16.92 & 6.20 & 0.32 \\
\hline EL- Joy 012 & 76.0 & 24.0 & 21.7 & 6.58 & 10.09 & 16.67 & 0.70 & 2.26 \\
\hline EL- Joy 013 & 80.0 & 20.0 & 16.0 & 2.59 & 6.98 & 9.57 & 0.50 & 2.23 \\
\hline EL- Joy 014 & 76.0 & 24.0 & 20.0 & 5.21 & 9.12 & 14.33 & 2.10 & 2.39 \\
\hline EL- Joy 015 & 78.0 & 22.0 & 19.4 & 4.55 & 8.84 & 13.39 & 0.50 & 2.50 \\
\hline Mean & 77.7 & 22.27 & 19.6 & 4.28 & 10.34 & 14.62 & 5.13 & 1.25 \\
\hline SD & 1.87 & 1.87 & 1.73 & 1.37 & 3.33 & 3.60 & 3.79 & 0.82 \\
\hline CV (\%) & 2.41 & 8.40 & 8.80 & 31.92 & 32.26 & 24.62 & 73.93 & 65.84 \\
\hline
\end{tabular}


The maximum amount of vitamin $\mathrm{C}$ was obtained from the variety BARI Anshphal-1 $(13.77 \mathrm{mg} / 100 \mathrm{~g})$ followed by the variety BARI Anshphal-2 (10.71 $\mathrm{mg} / 100 \mathrm{~g})$, whereas the minimum $(0.50 \mathrm{mg} / 100 \mathrm{~g})$ in the genotypes EL- Joy 013 and EL- Joy 015.

The highest amount of $\beta$-carotene was recorded in EL- Joy 015 (2.50 $\mathrm{mg} / 100 \mathrm{~g}$ ) followed by EL- Joy $014(2.39 \mathrm{mg} / 100 \mathrm{~g})$, EL- Joy 012 (2.26) and ELJoy $013(2.23 \mathrm{mg} / 100 \mathrm{~g})$, while the lowest was obtained from EL- Joy 004 (0.21 $\mathrm{mg} / 100 \mathrm{~g})$.

\section{Conclusions}

The findings of the present study will help selecting longan varieties/lines for fresh consumption, processing and variety development programmes. Considering the overall physical and chemical characteristics of fruits of all the studied germplasm, BARI Anshphal-1, BARI Anshphal-2, EL- Joy 003, EL- Joy 006, EL- Joy 009, EL- Joy 010 were found superior to other germplasm in respect of fruit weight, edible portion, TSS, total reducing, non-reducing sugar, and ascorbic acid.

\section{References}

Anonymous. 2007. Dimocarpus longan. Montoso Gardens, Hwy 120 Km 18.9, Box 692, Maricao, Puerto Rico 00606 USA (www.montosogardens.com/ dimocarpus_ longan.htm).

Morton, J. 1987. Longan. In: Fruits of warm climates. Julia F. Morton, Miami, FL. pp. 259-262.

Saifullah, M. 1996. Performance of longan (Nephelium longana) at Joydebpur. Annual Report on Fruit Improvement. 1995-1996. Pomology Division, Horticulture Research Centre, Bangladesh Agricultural Research Institute, Joydebpur, Gazipur1701. p.75-76.

Wong, K. C. and K. Saichol. 1991. Dimocarpus longan Lour. In: E.W.M. Verheij and R.E. Coronel (eds.) Edible fruits and nuts. Plant Resources of Southeast Asia, Pudoc, Wageningen. Pp. 146-151.

Wong, K.C. 2000. Longan Production in Asia. In: FAO Corporate Document Repository. Food and Agriculture Organization of the United Nations Regional office for Asia and The Pacific Bangkok, Thailand, December,2000. 39 p. 